www.nature.com/ja

\title{
Spirohexalines, new inhibitors of bacterial undecaprenyl pyrophosphate synthase, produced by Penicillium brasilianum FKI-3368
}

\author{
Junji Inokoshi $^{1}$, Yuichiro Nakamura ${ }^{1}$, Zhang Hongbin ${ }^{1}$, Ryuji Uchida ${ }^{1}$, Ken-ichi Nonaka ${ }^{2}$, Rokuro Masuma ${ }^{2}$ \\ and Hiroshi Tomoda ${ }^{1}$
}

An enzyme assay for bacterial undecaprenyl pyrophosphate (UPP) synthase was performed to screen microbial culture broths for inhibitors of UPP synthase. During the course of this screening program, an EtOH extract of a rice culture of Penicillium brasilianum FKI-3368 was found to inhibit UPP synthase activity. From activity-guided purification, a new compounddesignated spirohexaline was isolated together with the structurally related and known viridicatumtoxin by ethyl acetate extraction silica gel and octadecylsilane column chromatographies and high-performance liquid chromatography. The structure of spirohexaline was elucidated by spectroscopic analysis, including NMR. Spirohexaline and viridicatumtoxin have a common hexacycline structure produced by fusion of a tetracycline-type ring with a spiro-type ring. They inhibited UPP synthase activity with $\mathrm{IC}_{50}$ values of 9.0 and $4.0 \mu \mathrm{m}$, respectively.

The Journal of Antibiotics (2013) 66, 37-41; doi:10.1038/ja.2012.83; published online 21 November 2012

Keywords: cis-prenyltransferase; methicillin-resistant Staphylococcus aureus; spirohexaline; undecaprenyl pyrophosphate

\section{INTRODUCTION}

Antibiotic-resistant bacterial infections pose a major threat to public health. Methicillin-resistant Staphylococcus aureus (MRSA) is known as a nosocomial pathogen that has also developed resistance to many other antibiotics. Moreover, MRSA resistance to the last resort antibiotic, vancomycin, has been reported. ${ }^{1}$ These facts suggest that $S$. aureus will acquire full resistance to vancomycin in the near future. However, the past 30 years have seen only two new classes of antibiotics introduced into clinical use, represented by the natural product daptomycin and the synthetic oxazolidinone linezolid. Therefore, there is great need for the discovery and development of new anti-infective agents possessing a novel mechanism of action.

The bacterial cell wall is an attractive target for antibacterial agents because it is an essential bacteria-specific structure that is absent from human cells. ${ }^{2}$

Undecaprenyl pyrophosphate (UPP) is a key lipid involved in the biosynthesis of peptidoglycan and other cell wall polysaccharide components, such as lipopolysaccharides, enterobacterial common antigen, capsule polysaccharides and teichoic acids. UPP-linked saccharides are also used for $N$-linked protein glycosylation that occurs in certain prokaryotes. In the cell wall synthetic pathway, UPP is needed for the synthesis and transport of hydrophilic GlcNAcMurNAc-pentapeptides across the hydrophobic environment of the cytoplasmic membrane to the externally located sites of polymerization. Thus, UPP synthase inhibitors that cause specific growth inhibition against bacteria, including MRSA or vancomycin-resistant enterococcus, are anticipated to be useful clinical drugs because such inhibitors have yet to be used in clinical or agricultural fields.

Against this background, a screening system was established to search for UPP synthase inhibitors. We used it to discover a novel compound-designated spirohexaline (1) (Figure 1) from a culture of Penicillium brasilianum FKI-3368, statically fermented in a rice-based medium together with viridicatumtoxin (2). In this study, we describe the taxonomy of the producing fungus FKI-3368, the production, isolation and structural elucidation of $\mathbf{1}$ and $\mathbf{2}$.

\section{RESULTS}

Taxonomic studies

Colonies on Czapek yeast extract agar (CYA) after 7 days at $25^{\circ} \mathrm{C}$ (Figure 2a) were $50-55 \mathrm{~mm}$ in diameter, velutinous, radially sulcate, plane, with pale yellow (1 ca) aerial mycelium. The surface was covered with olive gray ( $1 \mathrm{ig}$ ) conidia, and the exudate was sparse and clear drops. The reverse side was pale yellow brown (2 ic), with an entire margin, without soluble pigment. Colonies on malt extract agar after 7 days at $25^{\circ} \mathrm{C}$ (Figure 2b) were $55-57 \mathrm{~mm}$ in diameter, velutinous to floccose, plane, with white mycelium, covered with mistletoe gray (24 1/2 ih) conidia. The reverse side was light olive gray 
( $11 / 2 \mathrm{ec}$ ), with an entire margin, without soluble pigment. Colonies on $25 \%$ glycerol nitrate agar after 7 days at $25^{\circ} \mathrm{C}$ (Figure 2c) were $17-18 \mathrm{~mm}$ in diameter, velutinous, plane, with white mycelium covered with moss gray (22 ih) conidia and lacking exudate; the reverse side was dull yellow (1 lc), with an entire margin, without soluble pigment. Colonies on CYA after 7 days at $37^{\circ} \mathrm{C}$ were 19 $20 \mathrm{~mm}$ in diameter, velutinous, radially sulcate and pulvinate. The surface was covered with white floccose aerial mycelium without exudate. The reverse side was ivory $(2 \mathrm{db})$, with an entire margin, without soluble pigment. Colonies on CYA at $5{ }^{\circ} \mathrm{C}$ showed no growth. Conidiophores on malt extract agar were borne on a basal felt or directly from the agar, stipes were simple, $50-250 \times 1.0-2.5 \mu \mathrm{m}^{2}$ and usually rough walled. Penicilli are typically biverticillate (Figure $2 \mathrm{~d}$ ). Metulae were in verticils of $2-5,7-9 \times 2.5-3.5 \mu \mathrm{m}^{2}$, and rough walled. Phialides were ampulliform, 2-4 per metula, $6.5-7.5 \times 2.5-3.5 \mu \mathrm{m}^{2}$, collula $0.5-1.5 \mu \mathrm{m}$ wide. Conidia, borne in chains, were globose to ellipsoidal, rough, $2.0-3.0 \times 2.0-2.5 \mu \mathrm{m}^{2}$ (Figure 2e). From the above

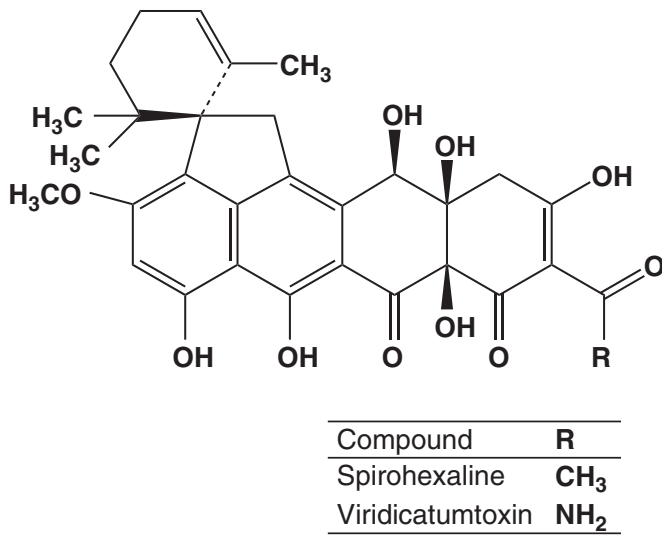

Figure 1 Structures of spirohexaline and viridicatumtoxin. morphological characteristics, strain FKI-3368 was classified in the genus Penicillium, subgenus Furcatum, section Furcatum and series Oxalica. Moreover, from the yellow reverse color on CYA and ellipsoidal conidia, this strain corresponded to P. brasilianum Bat. ${ }^{3,4}$

In a BLAST search using the Blastn program from the National Center for Biotechnology Information (NCBI), ${ }^{5}$ the nucleotide sequences of the internal transcribed spacer (ITS), beta-tubulin gene and calmodulin gene from FKI-3368 showed 99-100\% similarity with those of P. brasilianum CBS 253.55 (ex-type) (GenBank accession numbers GU981577, GU981629 and AB667857).

From these results, the producing strain FKI-3368 was identified as P. brasilianum and was deposited at the International Patent Organism Depository, National Institute of Advanced Industrial Science and Technology, Tsukuba, Japan, as FERM P-21369.

\section{Fermentation and purification of spirohexaline (1) and viridicatumtoxin (2)}

P. brasilianum FKI-3368 was cultured statically in 500-ml Erlenmeyer flasks, each containing $50 \mathrm{~g}$ of Italian rice and $0.5 \mathrm{~g}$ of seaweed powder at $27^{\circ} \mathrm{C}$ for 15 days. The fermentation materials containing the mycelium ( $2 \mathrm{~kg}$ ) were extracted with $50 \%$ ethanol (21). After the ethanol extracts were filtered and concentrated to remove ethanol, the aqueous residue was extracted with ethyl acetate. The extracts were dried over $\mathrm{Na}_{2} \mathrm{SO}_{4}$ and concentrated in vacuo to dryness to yield crude materials $(15.9 \mathrm{~g})$. The materials were subjected to silica gel column chromatography $(70 \times 190 \mathrm{~mm})$, and eluted stepwise with 100:0, 99:1, 98:2, 96:4, 90:10 and 0:100 (v/v) of $\mathrm{CHCl}_{3}-\mathrm{CH}_{3} \mathrm{OH}$ solvents (2l each). The 99:1 and 98:2 fractions $\left(\mathrm{CHCl}_{3}-\mathrm{CH}_{3} \mathrm{OH}\right)$ showing the activity were concentrated to give a dark yellow powder $(10.2 \mathrm{~g})$. The powder was subjected to octadecylsilane column chromatography $(70 \times 120 \mathrm{~mm}$, Senshu Sci. Co. Ltd., Tokyo Japan), followed by stepwise elution with 40,50, 60, 70, 80 and $90 \% \mathrm{CH}_{3} \mathrm{CN}$ (11 each). The active fractions eluted from 60 and $70 \% \mathrm{CH}_{3} \mathrm{CN}$ were combined and concentrated to give enriched $\mathbf{1}$ and $\mathbf{2}$ as yellow
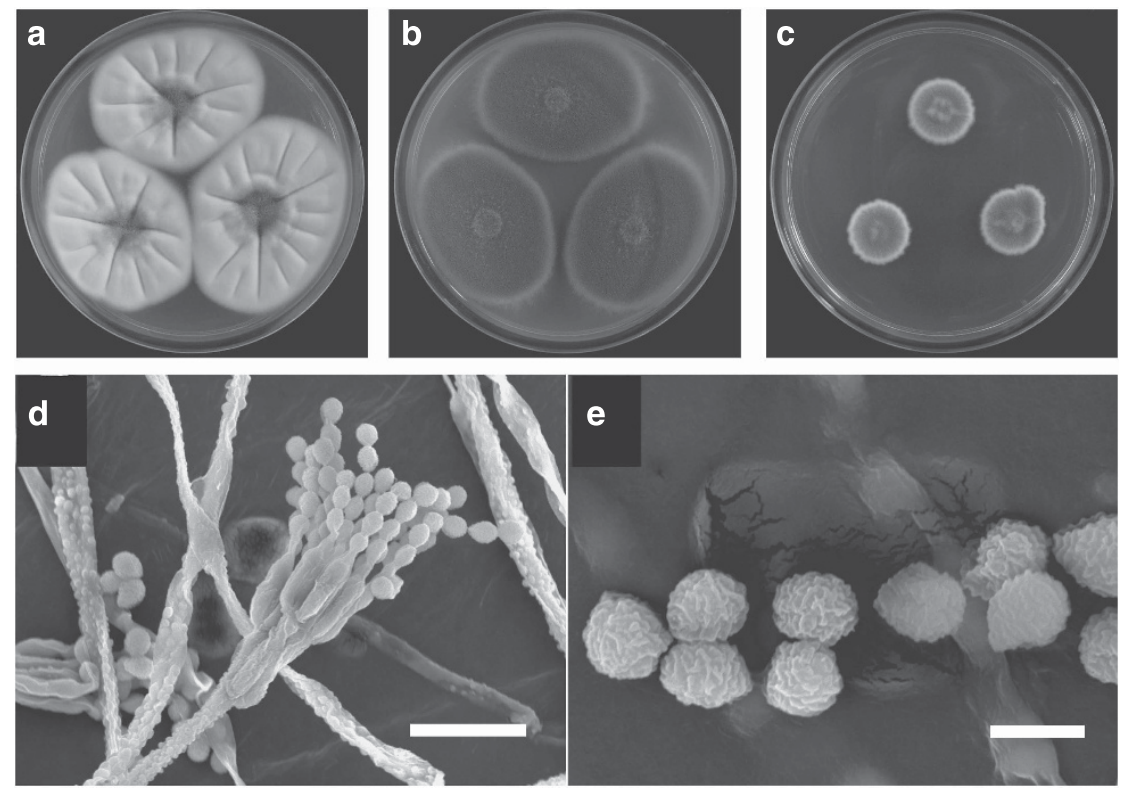

Figure 2 Morphological characteristics of $P$. brasilianum FKI-3368. (a) Photograph of colonies grown on $\mathrm{CYA}$ at $25^{\circ} \mathrm{C}$ for 7 days. (b) Photograph of colonies grown on malt extract agar at $25^{\circ} \mathrm{C}$ for 7 days. (c) Photograph of colonies grown on $25 \%$ glycerol nitrate agar at $25^{\circ} \mathrm{C}$ for 7 days. (d) Scanning electron micrograph of penicillas of strain FKI-3368 grown on SEM. (e) Scanning electron micrograph of conidia of strain FKI-3368 grown on SEM. Bar represents $10 \mu \mathrm{m}$. A full color version of this figure is available at The Journal of Antibiotics journal online. 
powder $(631 \mathrm{mg})$. The yellow powder was finally purified with preparative high-performance liquid chromatography (column, PEGASIL ODS (Senshu Sci. Co. Ltd.), $20 \times 250 \mathrm{~mm}$; solvent, $60 \% \mathrm{CH}_{3} \mathrm{CN}$ containing $0.05 \% \mathrm{H}_{3} \mathrm{PO}_{4}$; detection, $\mathrm{UV}$ at $280 \mathrm{~nm}$; flow rate, $7.0 \mathrm{ml} \mathrm{min}^{-1}$ ). Under these conditions, 1 and 2 were eluted as peaks with retention times of 62 and $30 \mathrm{~min}$, respectively. Each fraction was pooled, concentrated and extracted with ethyl acetate, which was concentrated in vacuo to dryness to give pure $\mathbf{1}(11.7 \mathrm{mg})$ and $2(276 \mathrm{mg})$ as yellow materials.

\section{Structural elucidation of spirohexaline (1)}

The physicochemical properties of spirohexaline (1) are summarized in Table 1 and the data of 2 also shown in Table 1 are comparable with those of viridicatumtoxin as previously reported. In addition, independent interpretation of the ${ }^{1} \mathrm{H}$ - and ${ }^{13} \mathrm{C}$-NMR spectra together with the ${ }^{1} \mathrm{H}-{ }^{1} \mathrm{H}$ COSY, DEPT, HMQC and HMBC spectra led to the identification of 2 as viridicatumtoxin. ${ }^{6}$

Compound 1 had absorption maxima at 239 and $281 \mathrm{~nm}$ in the UV-visible spectrum. The IR absorption at 3438 and $1625 \mathrm{~cm}^{-1}$ suggested the presence of hydroxyl and carbonyl groups in the structure. These data of $\mathbf{1}$ are similar to those of $\mathbf{2}$, indicating that they have the same skeleton. The molecular formula of $\mathbf{1}$ was determined as $\mathrm{C}_{31} \mathrm{H}_{32} \mathrm{O}_{10}$ on the basis of the HRESI-MS measurement of $\mathrm{m} / \mathrm{z}$ of 563.1900 , calcd 563.1917 for $\mathrm{C}_{31} \mathrm{H}_{31} \mathrm{O}_{10}$ $(\mathrm{M}-\mathrm{H})^{-}$, indicating that in 1 , a nitrogen atom is replaced by one carbon atom and one hydrogen atom. The ${ }^{1} \mathrm{H}$ - and ${ }^{13} \mathrm{C}-\mathrm{NMR}$ spectral (in chloroform- $d_{1}$ ) data are shown in Table 2 . The ${ }^{13} \mathrm{C}$-NMR spectrum of 1 showed 31 signals, which were classified into four methyl carbons, one methoxy carbon, four methylene carbons, one oxygenated $\mathrm{sp}^{3}$ methine carbon, two $\mathrm{sp}^{2}$ methine carbons, two $\mathrm{sp}^{3}$ quaternary carbons, two oxygenated $\mathrm{sp}^{3}$ quaternary carbons, eight $\mathrm{sp}^{2}$ quaternary carbons, four oxygenated $\mathrm{sp}^{2}$ quaternary carbons and three ketone carbonyl carbons by analysis of DEPT spectra (Table 2). These spectral data of $\mathbf{1}$ were similar to those of $\mathbf{2}$. The major difference between $\mathbf{1}$ and 2 in ${ }^{1} \mathrm{H}$ - and ${ }^{13} \mathrm{C}-\mathrm{NMR}$ data is that one methyl carbon $\left(\delta_{\mathrm{C}} 27.7\right.$, $\left.\delta_{\mathrm{H}} 2.73\right)$ was newly observed in 1 instead of the $\mathrm{NH}_{2}\left(\delta_{\mathrm{H}} 5.92,9.08\right)$ in 2. In addition, the amino carbonyl carbon of C-13 of 1 was downfield-shifted from $\delta 172.7$ to $\delta$ 202.2. These spectral data together with the molecular formula suggested that a $\mathrm{NH}_{2}$ group replaced a methyl group at $\mathrm{C}-13$. Furthermore, the presence of the methyl group at $\mathrm{C}-13$ was determined by the $\mathrm{HMBC}$ spectrum (Figure 3). The methyl proton at $\delta 2.73\left(\mathrm{H}_{3}-21\right)$ was long-rangecoupled to the $\mathrm{sp}^{2}$ quaternary carbon at $\mathrm{C}-2(\delta$ 110.5) and the

Table 1 Physicochemical properties of 1 and 2

\begin{tabular}{|c|c|c|}
\hline & Spirohexaline (1) & Viridicatumtoxin (2) \\
\hline Appearance & Bright yellow pigment & Bright yellow pigment \\
\hline $\begin{array}{l}\text { Molecular } \\
\text { formula }\end{array}$ & $\mathrm{C}_{31} \mathrm{H}_{32} \mathrm{O}_{10}$ & $\mathrm{C}_{30} \mathrm{H}_{31} \mathrm{NO}_{10}$ \\
\hline $\begin{array}{l}\text { HRFAB-MS }(m / z) \\
\text { Found }\end{array}$ & $563.1900(\mathrm{M}-\mathrm{H})^{-}$ & $565.1962(\mathrm{M}+)$ \\
\hline Calcd & 563.1917 & 565.1948 \\
\hline $\begin{array}{l}\text { UV(EtOH) } \lambda_{\max } \\
\mathrm{nm}(\varepsilon)\end{array}$ & $\begin{array}{l}\text { 239(20 100), 281(35800), } \\
423(8100)\end{array}$ & $\begin{array}{l}237(21900), 285(32900), \\
424(8100)\end{array}$ \\
\hline $\begin{array}{l}{[\alpha]_{\mathrm{D}}(c=1.0} \\
\text { EtOH })\end{array}$ & $+13^{\circ}$ & $+12^{\circ}$ \\
\hline $\mathrm{IR} \gamma_{\max }\left(\mathrm{cm}^{-1}\right)$ & $\begin{array}{l}3438,2958,2925,1733 \\
1625,1596\end{array}$ & $\begin{array}{l}3550-3350,2980,1725 \\
1650,1620,1595\end{array}$ \\
\hline
\end{tabular}

ketone carbonyl carbons at C-13 ( $\delta 202.2)$, indicating that the methyl group is present at $\mathrm{C}-13$. The remaining structure was also confirmed by ${ }^{1} \mathrm{H}-{ }^{1} \mathrm{H}$ COSY and HMBC spectra. Thus, the structure of 1 was assigned as shown in Figure 1.

\section{Inhibition of UPP synthase and antimicrobial activities}

UPP synthase activity was measured by the enzyme-coupled fluorescent method. ${ }^{7}$ Compounds 1 and 2 inhibited UPP synthase activity with IC $_{50}$ values of $9.0 \mu \mathrm{M}$ and $4.0 \mu \mathrm{M}$, respectively (Figure 4). Compound 1 exhibited potent antimicrobial activity against $S$. aureus and clinically isolated MRSA with minimal inhibitory concentration values of $1.56 \mu \mathrm{g} \mathrm{ml}^{-1}$ and $6.25 \mu \mathrm{g} \mathrm{ml}^{-1}$, respectively.

\section{DISCUSSION}

As described in this study, spirohexaline and viridicatumtoxin (Figure 1) were isolated from the culture broth of $P$. brasilianum FKI-3368. They are potent inhibitors of bacterial UPP synthase. Furthermore, as we expected, spirohexaline was found to show potent antibacterial activity against Gram-positive bacteria, including MRSA, as described in an accompanying study. UPP synthase is an attractive target for the development of a new type of antimicrobial agents. Indeed, high-throughput screening for UPP synthase was performed by several groups. ${ }^{8-10}$ The Novartis group reported that tetramic acid derivatives were potent inhibitors of Staphylococcus pneumonia UPP synthase, and Liang's group obtained sulfonylbiscontaining synthetic compound (BTB06061) as a potent and selective inhibitor of Helicobacter pylori UPP synthase. Furthermore, from the analysis of the X-ray structures of UPP synthase-substrate (for example, farnesyl diphosphate)/inhibitors (for example, bisphosphonate drugs) complexes and the computational modeling of substrate/inhibitors of UPP synthase, more potent inhibitors have been developed. ${ }^{11-13}$ However, even though such compounds inhibited UPP synthase, their antimicrobial activity was not described in most cases. ${ }^{8,10-13}$ It might be that the inhibitory activity against UPP synthase cannot reflect the antimicrobial activity. Among the UPP synthase inhibitors reported so far, tetramic acid derivative 4 a showed very potent $S$. aureus UPP synthase ( $\left.\mathrm{IC}_{50}, 0.2 \mu \mathrm{M}\right)$ and antimicrobial activities against Enterococcus fecalis (minimal inhibitory concentration, $8.0 \mu \mathrm{g} \mathrm{ml}^{-1}$ ), $S$. aureus $\left(4.0 \mu \mathrm{g} \mathrm{ml}^{-1}\right)$ and $S$. pneumonia $\left(4.0 \mu \mathrm{g} \mathrm{ml}^{-1}\right)$. Unfortunately, the derivative $4 \mathrm{a}$ showed decreased inhibitory activity in serum. In this study, we demonstrated that spirohexaline and viridicatumtoxin are potent UPP synthase inhibitors with antimicrobial activities against Gram-positive bacteria. The structures are classified into tetracycline-type antibiotics and do not resemble the substrate FPP. Thus, spirohexaline might not interact with the substrate-binding site on UPP synthase. Viridicatumtoxin was originally isolated as a mycotoxin; ${ }^{14}$ the single-dose $\mathrm{LD}_{50}$ in mice was described as $122.4 \mathrm{mg} \mathrm{kg}^{-1}$ in the initial report, but nonlethal oral administration up to $350 \mathrm{mg} \mathrm{kg}^{-1}$ in mice was described in a later study, ${ }^{15}$ indicating that viridicatumtoxin showed very low cytotoxicity. Spirohexaline and viridicatumtoxin are of interest as new lead compounds of UPP synthase inhibitors. Further investigation on their biological properties will be reported shortly.

\section{METHODS}

Bacterial strains, plasmid, enzymes and chemicals

The E. coli strains used in this study were JM109 (Takara Bio Inc., Shiga, Japan) and BL21 (DE3) (Merck KGaA, Darmstadt, Germany). The strains were grown in Luria-Bertani (LB) medium (Becton, Dickinson and Company, Franklin Lakes, NJ, USA) with aeration at $37^{\circ} \mathrm{C}$. Plasmid pET-42b was from 
Table $2{ }^{1} \mathrm{H}$ and ${ }^{13} \mathrm{C}$ NMR data of 1 and 2

\begin{tabular}{|c|c|c|c|c|c|}
\hline \multicolumn{3}{|c|}{ Chemical shift for spirohexaline (1) } & \multicolumn{3}{|c|}{ Chemical shift for viridicatumtoxin (2) } \\
\hline Position & ${ }^{13} \mathrm{C}$ & ${ }^{1} H$ & Position & ${ }^{13} \mathrm{C}$ & ${ }^{1} H$ \\
\hline 1 & $190.2 \mathrm{~s}$ & & 1 & $190.4 \mathrm{~s}$ & \\
\hline 2 & $110.5 \mathrm{~s}$ & & 2 & $99.5 s$ & \\
\hline 3 & $194.4 \mathrm{~s}$ & & 3 & $192.8 s$ & \\
\hline \multirow[t]{2}{*}{4} & $40.6 \mathrm{t}$ & $2.82 \mathrm{~d}(1 \mathrm{H}, J=20 \mathrm{~Hz})$ & 4 & $40.3 t$ & $2.76 \mathrm{dd}(1 \mathrm{H}, J=20 \mathrm{~Hz})$ \\
\hline & & $2.88 \mathrm{~d}(1 \mathrm{H}, J=20 \mathrm{~Hz})$ & & & $2.82 \mathrm{dd}(1 \mathrm{H}, J=18 \mathrm{~Hz})$ \\
\hline $4 a$ & $71.1 \mathrm{~s}$ & & $4 a$ & $71.5 \mathrm{~s}$ & \\
\hline 5 & $71.5 d$ & 4.48br.s $(1 \mathrm{H})$ & 5 & $71.6 d$ & 4.5br.s $(1 \mathrm{H})$ \\
\hline $5 a$ & $123.7 \mathrm{~s}$ & & $5 a$ & $123.8 \mathrm{~s}$ & \\
\hline 6 & $137.1 \mathrm{~s}$ & & 6 & $137.0 \mathrm{~s}$ & \\
\hline $6 a$ & $147.1 \mathrm{~s}$ & & $6 a$ & $147.1 \mathrm{~s}$ & \\
\hline 7 & $122.7 \mathrm{~s}$ & & 7 & $122.6 \mathrm{~s}$ & \\
\hline 8 & $160.7 \mathrm{~s}$ & & 8 & $160.7 \mathrm{~s}$ & \\
\hline 9 & $99.9 d$ & $6.65 \mathrm{~s}(1 \mathrm{H})$ & 9 & $99.9 d$ & $6.65 \mathrm{~s}(1 \mathrm{H})$ \\
\hline 10 & $157.9 s$ & & 10 & $157.9 s$ & \\
\hline $10 a$ & $105.4 \mathrm{~s}$ & & $10 a$ & $105.4 \mathrm{~s}$ & \\
\hline 11 & $165.9 s$ & & 11 & $165.9 \mathrm{~s}$ & \\
\hline $11 a$ & $105.1 \mathrm{~s}$ & & $11 a$ & 105.0s & \\
\hline 12 & $195.3 \mathrm{~s}$ & & 12 & $195.2 \mathrm{~s}$ & \\
\hline $12 a$ & $80.6 s$ & & $12 a$ & $80.1 \mathrm{~s}$ & \\
\hline 13 & $202.2 \mathrm{~s}$ & & 13 & $172.7 \mathrm{~s}$ & \\
\hline \multirow[t]{2}{*}{14} & $41.1 \mathrm{t}$ & 2.93d $(1 \mathrm{H}, J=17 \mathrm{~Hz})$ & 14 & $41.1 \mathrm{t}$ & $2.93 \mathrm{~d}(1 \mathrm{H}, J=20 \mathrm{~Hz})$ \\
\hline & & $3.44 \mathrm{~d}(1 \mathrm{H}, J=17 \mathrm{~Hz})$ & & & $3.44 \mathrm{~d}(1 \mathrm{H}, J=20 \mathrm{~Hz})$ \\
\hline 15 & $60.1 \mathrm{~s}$ & & 15 & $60.1 \mathrm{~s}$ & \\
\hline 16 & $136.5 \mathrm{~s}$ & & 16 & $136.6 \mathrm{~s}$ & \\
\hline 17 & $121.4 d$ & 5.51 br.s $(1 \mathrm{H})$ & 17 & $121.3 d$ & 5.51 br.s $(1 \mathrm{H})$ \\
\hline \multirow[t]{2}{*}{18} & $22.8 \mathrm{t}$ & $2.02 \mathrm{~m}(1 \mathrm{H})$ & 18 & $22.8 \mathrm{t}$ & $2.02 \mathrm{~m}(1 \mathrm{H})$ \\
\hline & & $2,20 \mathrm{~m}(1 \mathrm{H})$ & & & $2.20 \mathrm{~m}(1 \mathrm{H})$ \\
\hline \multirow[t]{2}{*}{19} & $33.8 \mathrm{t}$ & 1.34dd $(1 \mathrm{H}, J=6,13 \mathrm{~Hz})$ & 19 & $33.8 t$ & $1.34 \mathrm{dd}(1 \mathrm{H}, J=6,13 \mathrm{~Hz})$ \\
\hline & & $1.84 d d d(1 \mathrm{H}, J=6,12,12 \mathrm{~Hz})$ & & & 1.84ddd $(1 \mathrm{H}, J=3,13,13 \mathrm{~Hz})$ \\
\hline 20 & $38.5 \mathrm{~s}$ & & 20 & $38.5 \mathrm{~s}$ & \\
\hline 21 & $27.7 q$ & $2.73 \mathrm{~s}(3 \mathrm{H})$ & 21 & $23.9 q$ & $1.53 \mathrm{~s}(3 \mathrm{H})$ \\
\hline 22 & $23.9 q$ & $1.53 \mathrm{~s}(3 \mathrm{H})$ & 22 & $25.4 q$ & $0.47 \mathrm{~s}(3 \mathrm{H})$ \\
\hline 23 & $25.4 q$ & $0.48 \mathrm{~s}(3 \mathrm{H})$ & 23 & $20.9 q$ & $0.91 \mathrm{~s}(3 \mathrm{H})$ \\
\hline 24 & $21.0 q$ & $0.91 \mathrm{~s}(3 \mathrm{H})$ & 24 & $55.5 q$ & $3.87 \mathrm{~s}(3 \mathrm{H})$ \\
\hline 25 & $55.5 q$ & $3.87 \mathrm{~s}(3 \mathrm{H})$ & $3-\mathrm{OH}$ & & $17.9 \mathrm{~s}(1 \mathrm{H})$ \\
\hline $3-\mathrm{OH}$ & & $18.1 \mathrm{~s}(1 \mathrm{H})$ & $4 \mathrm{a}-\mathrm{OH}$ & & $4.15 \mathrm{~s}(1 \mathrm{H})$ \\
\hline $4 \mathrm{a}-\mathrm{OH}$ & & $4.10 \mathrm{~s}(1 \mathrm{H})$ & $5-\mathrm{OH}$ & & 3.04br.d $(1 \mathrm{H} \mathrm{J}=10 \mathrm{~Hz})$ \\
\hline $5-\mathrm{OH}$ & & $3.02 \mathrm{~d}(1 \mathrm{H}, J=12 \mathrm{~Hz})$ & $10-\mathrm{OH}$ & & 8.68br.s $(1 \mathrm{H})$ \\
\hline $10-\mathrm{OH}$ & & $8.68 \mathrm{~s}(1 \mathrm{H})$ & $11-\mathrm{OH}$ & & 14.79br.s $(1 \mathrm{H})$ \\
\hline $11-\mathrm{OH}$ & & $14.73 \mathrm{~s}(1 \mathrm{H})$ & $12 \mathrm{a}-\mathrm{OH}$ & & 5.28br.s (1H) \\
\hline \multirow[t]{2}{*}{$12 \mathrm{a}-\mathrm{OH}$} & & 5.4br.s $(1 \mathrm{H})$ & $13-\mathrm{NH}_{2}$ & & 5.92br.s $(1 \mathrm{H})$ \\
\hline & & & & & 9.08br.s $(1 \mathrm{H})$ \\
\hline
\end{tabular}

Novagen (Abingdon, England). Restriction enzymes were from New England Biolabs (Beverly, MA, USA) or Takara Bio Inc. and used as specified by the manufacturers. Amplex red was from Invitrogen (Carlsbad, CA, USA). $\left[1-{ }^{14} \mathrm{C}\right] \mathrm{IPP}(1.48 \mathrm{GBq} / \mathrm{mmol})$ was from PerkinElmer (Waltham, MA, USA). Pre-coated reversed-phase thin layer chromatography (TLC) plate, RP-18, was from GE Healthcare (Waukesha, WI, USA). All other chemicals were from Sigma (St Louis, MO, USA).

\section{General experimental procedures}

Fungal strain FKI-3368 was originally isolated from a soil sample collected on the Island of Hawaii, HI, USA. This strain was used for the production of 1 and 2 .

UV spectra were recorded on a spectrophotometer (8453 UV-visible spectrophotometer; Agilent Technologies, Santa Clara, CA, USA). IR spectra were recorded on a Fourier transform infrared spectrometer (FT-710, Horiba, Kyoto, Japan). Optical rotations were measured with a digital polarimeter
(DIP-1000, JASCO, Tokyo, Japan). FAB-MS spectra were recorded on a mass spectrometer (JMS-DX300, JEOL, Tokyo, Japan) and HRFAB-MS spectra were recorded on a mass spectrometer (JMS-AX505 HA, JEOL). The various NMR spectra were measured with a spectrometer (XL-400, Varian, Palo Alto, CA, USA).

\section{Taxonomic studies}

For determination of the morphological characteristics using the methodology of Pitt, ${ }^{16}$ the isolate was inoculated as 3-point cultures on CYA, malt extract agar and $25 \%$ glycerol nitrate agar, and grown for 7 days at $25^{\circ} \mathrm{C}$ (also at 5 and $37^{\circ} \mathrm{C}$ on CYA) in the dark. Color Harmony Manual 4th Edition (Container Corporation of America, Chicago, IL, USA) was used to determine color names and hue numbers. ${ }^{17}$

For the determination of micromorphological characteristics, microscope slides were prepared using malt extract agar. The slides were examined with a Vanox-S AH-2 microscope (Olympus, Tokyo, Japan). 


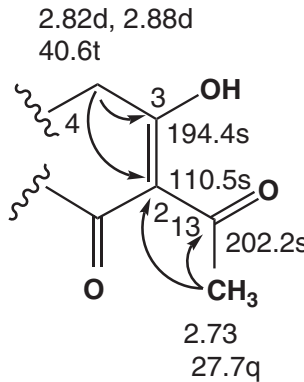

Spirohexaline

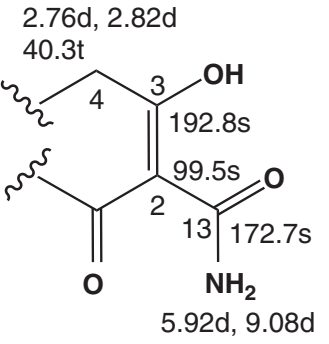

Viridicatumtoxin

\section{$\overbrace{\text { key HMBC }}$}

Figure 3 HMBC correlation of spirohexaline.

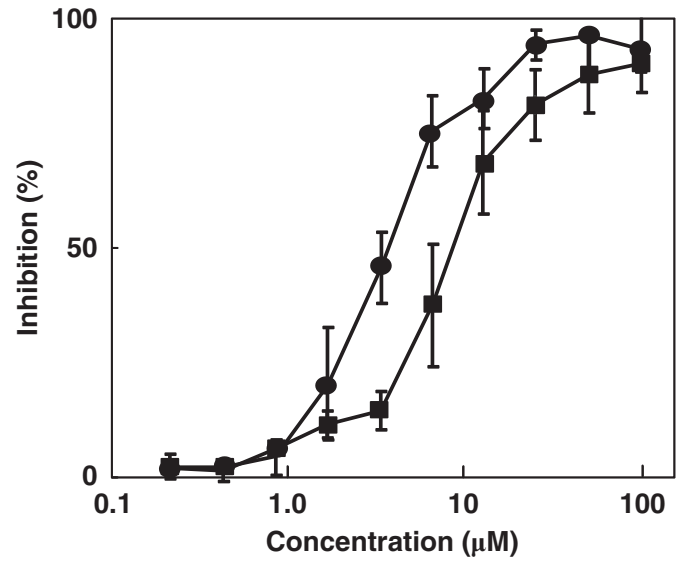

Figure 4 Inhibition of UPP synthase by spirohexaline viridicatumtoxin (-)

Genomic DNA of the fungal strain FKI-3368 was isolated using the PrepMan Ultra Sample Preparation Reagent (Applied Biosystems, Foster City, CA, USA) following the manufacturer's instructions. Amplifications of the ribosomal RNA gene (rDNA) ITS region, including the $5.8 \mathrm{~S}$ rDNA, the partial beta-tubulin gene region and the partial calmodulin gene region, were performed using primers ITS1 and ITS $4^{18}$ for the ITS region, primers Bt2a and $\mathrm{Bt} 2 \mathrm{~b}^{19}$ for the beta-tubulin gene region and primers CF1 and $\mathrm{CF} 4^{20}$ for the calmodulin gene region. Amplifications were performed in a PCR Verity 96-well thermal cycler (Applied Biosystems) and the PCR products were purified using a QIAquick, PCR DNA Purification kit protocol (Qiagen Inc., Valencia, CA, USA). The PCR products were sequenced using a BigDye Terminator v3.1 Cycle Sequencing Kit (Applied Biosystems). Sequencing products were purified using DyeEX 2.0 Spin Kit (Qiagen), and samples were analyzed on an ABI PRISM 3130 Genetic Analyzer (Applied Biosystems). Contigs were assembled using the forward and reverse sequences with the SeqMan and SeqBuilder programs from the Lasergene 9 package (DNAStar Inc., Madison, WI, USA). The DNA sequences of the strain FKI-3368 were deposited at the DNA Data Bank of Japan (DDBJ) with accession numbers AB455514 (ITS), AB667855 ( $\beta$-tubulin) and AB667856 (calmodulin).

\section{UPP synthase assays}

UPP synthase reaction was measured by a coupling assay, a modification of the method of Vazquez et al. ${ }^{7}$, for inorganic phosphate determination. Reactions were performed in black 96-well plates from DS Pharma Biomedical Co. Ltd. (Osaka, Japan). UPP synthase was incubated at $37^{\circ} \mathrm{C}$ with $5 \mathrm{mU}$ of inorganic pyrophosphatase from Saccharomyces cerevisiae in a total reaction volume of $100 \mu$ containing $100 \mathrm{~mm}$ Tris- $\mathrm{HCl}(\mathrm{pH} 7.5), 0.5 \mathrm{~mm} \mathrm{MgCl}, 50 \mathrm{~mm} \mathrm{KCl}$,
$3.5 \mu \mathrm{M}$ IPP, $0.5 \mu \mathrm{M}$ FPP and $0.005 \%$ (wt/vol) Triton X-100. The reaction was terminated after $30 \mathrm{~min}$ by the addition of $10 \mu \mathrm{l}$ of $0.5 \mathrm{~m}$ EDTA and quenched with $100 \mu \mathrm{l}$ of a cocktail containing $100 \mathrm{~mm}$ Tris- $\mathrm{HCl}$ ( $\mathrm{pH}$ 7.4), $3 \mathrm{~mm}$ inosine, $0.2 \mathrm{mU} \mathrm{ml}^{-1}$ PNP, $10 \mathrm{mU} \mathrm{ml}^{-1}$ horseradish peroxidase, $4 \mathrm{mU} \mathrm{ml}^{-1} \mathrm{XOD}$ and $0.1 \mathrm{~mm}$ Amplex red. After another $30 \mathrm{~min}$ of incubation at room temperature, the plate was read at $530 / 590 \mathrm{~nm}$. The amount of phosphate released from IPP was calculated from a standard curve prepared with $\mathrm{KH}_{2} \mathrm{PO}_{4}$.

\section{Other analytical methods}

Protein concentrations were determined using BCA protein assay kit (Thermo Fisher Scientific Inc., Waltham, MA, USA). Minimal inhibitory concentrations were measured by the agar dilution method using Mueller Hinton Agar (BD, Franklin Lakes, NJ, USA). Freshly grown cells (or spores) of S. aureus ATCC6538p (methicillin-susceptible (MSSA)) and S. aureus K24 (MRSA) were inoculated and grown at $37^{\circ} \mathrm{C}$ for bacteria.

\section{ACKNOWLEDGEMENTS}

This work was supported in part by Grant-in-Aid for Scientific Research (B) 18390008 (to HT) from the Ministry of Education, Culture, Sports, Science and Technology, Japan, and by the Uehara Memorial Foundation (to HT).

1 Hiramatsu, K. et al. Methicillin-resistant Staphylococcus aureus clinical strain with reduced vancomycin susceptibility. J. Antimicrob. Chemother. 40, 135-136 (1997).

2 Walsh, C. T. Antibiotics: Actions, Origins, Resistance (ASM Press, Washington, DC, 2003).

3 Batista, A. C. \& Maia, H. da Silva. Alguns Penicillia de contaminação. Anais Soc. Biol. Pernambuco 15, 149-180 (1957).

4 Tuthill, D. E., Frisvad, J. C. \& Christensen, M. Systematics of Penicillium simplicissimum based on rDNA sequences, morphology and secondary metabolites. Mycologia 93, 298-308 (2001).

5 Altschul, S. F., Gish, W., Miller, W., Myers, E. W. \& Lipman, D. J. Basic local alignment search tool. J. Mol. Biol. 215, 403-410 (1990).

6 Kabuto, C. et al. X-Ray structure of viridicatumtoxin: a new class of mycotoxin from Penicillium viridicatum Westling. J. Chem. Soc. Chem. Commun. 728-729 (1976).

7 Vazquez, M. J., Rodriguez, B., Zapatero, C. \& Tew, D. G. Determination of phosphate in nanomolar range by an enzyme-coupling fluorescent method. Anal. Biochem. 320, 292-298 (2003).

$8 \mathrm{Li}, \mathrm{H}$. et al. The effect of triton concentration on the activity of undecaprenyl pyrophosphate synthase inhibitors. J. Biomol. Screening 8, 712-715 (2003).

9 Peukert, S. et al. Design and structure-activity relationships of potent and selective inhibitors of undecaprenyl pyrophosphate synthase (UPPS): tetramic, tetronic acids and dihydropyridin-2-ones. Bioorg. Med. Chem. Lett. 18, 1840-1844 (2008).

$10 \mathrm{Kuo}, \mathrm{C}$. J. et al. Structure-based inhibitors exhibit differential activities against Helicobacter pylori and Escherichia coli undecaprenyl pyrophosphate synthases. J. Biomed. Biotechnol. 2008, 1-6 (2008).

11 Scholte, A. A., Eubanks, L. M., Poulter, C. D. \& Vederas, J. C. Synthesis and biological activity of isopentenyl diphosphate analogues. Bioorg. Med. Chem. 12, 763-770 (2004).

12 Guo, R. T. et al. Bisphosphonates target multiple sites in both cis- and transprenyltransferases. Proc. Natl Acad. Sci. USA 104, 10022-10027 (2007).

13 Durrant, J. D. et al. Non-bisphosphonate inhibitors of isoprenoid biosynthesis identified via computer-aided drug design. Chem. Biol. Drug Des. 78, 323-332 (2011).

14 Hutchison, R. D., Steyn, P. S. \& Van Rensburg, S. J. Viridicatumtoxin, a new mycotoxin from Penicillium viridicatum Westling. Toxicol. Appl. Pharmacol. 24, 507-509 (1973).

15 Bendele, A. M., Carlton, W. W., Nelson, G. E., Peterson, R. E. \& Grove., M. D. Viridicatumtoxin mycotoxicosis in mice and rats. Toxicol. Lett. 22, 287-291 (1984).

16 Pitt, J. I. The Genus Penicillium, and its Teleomorphic States Eupenicillium and Talaromyces. 1-634 (Academic Press, London, 1979).

17 Jacobson, E., Granville, W. C. \& Foss, C. E. Color harmony manual. 4th edn (Container Corporation of America, Chicago, 1958).

18 White, T. J., Bruns, T., Lee, S. \& Taylor, J. Amplification and direct sequencing of fungal ribosomal RNA genes for phylogenetics. in PCR protocols: a guide to methods and applications (eds Innis, M. A., Gelfand, D. H., Sninsky, J. J. \& White, T. J.) 315-322 (Academic Press, New York, 1990).

19 Glass, N. L. \& Donaldson, G. Development of primer sets designed for use with the PCR to amplify conserved genes from filamentous ascomycetes. Appl. Environ. Microbiol 61, 1323-1330 (1995).

20 Peterson, S. W., Vega, F. E., Posada, F. \& Nagai, C. Penicillium coffeae, a new endophytic species isolated from a coffee plant and its phylogenetic relationship to $P$. fellutanum, $P$. thiersii and $P$. brocae based on parsimony analysis of multilocus DNA sequences. Mycologia 97, 659-666 (2005). 